\title{
Psychological interventions for behavioral adjustments in diabetes care - a value-based approach to disease control
}

This article was published in the following Dove Press journal:

Psychology Research and Behavior Management

\author{
Boon-How Chew' \\ Aaron Fernandez ${ }^{2}$ \\ Sazlina Shariff-Ghazali' \\ 'Department of Family Medicine, \\ Faculty of Medicine and Health \\ Sciences, Universiti Putra Malaysia, \\ Serdang, Selangor, Malaysia; \\ ${ }^{2}$ Department of Psychiatry, Faculty \\ of Medicine and Health Sciences, \\ Universiti Putra Malaysia, Serdang, \\ Selangor, Malaysia
}

Correspondence: Boon-How Chew Department of Family Medicine, Faculty of Medicine and Health Sciences, Universiti Putra Malaysia, 43400 Serdang, Selangor, Malaysia

Tel +60389472520

Fax +60389472328

Email chewboonhow@upm.edu.my

\begin{abstract}
Psychological aspects of a person, such as the personal value and belief systems, cognition and emotion, form the basis of human health behaviors, which, in turn, influence selfmanagement, self-efficacy, quality of life, disease control and clinical outcomes in people with chronic diseases such as diabetes mellitus. However, psychological, psychosocial and behavioral interventions aimed at these groups of patients have yielded inconsistent effects in terms of clinical outcomes in clinical trials. This might have been due to differing conceptualization of health behavioral theories and models in the interventions. Assimilating different theories of human behavior, this narrative review attempts to demonstrate the potential modulatory effects of intrinsic values on cognitive and affective health-directed interventions. Interventions that utilize modification of cognition alone via education or that focuses on both cognitive and emotional levels are hardly adequate to initiate health-seeking behavior and much less to sustain them. People who are aware of their own personal values and purpose in life would be more motivated to practice good health-related behavior and persevere in them.
\end{abstract}

Keywords: behavioral medicine, psychological theory, long-term care, diabetes care, selfmanagement, self-efficacy, chronic diseases

\section{Introduction}

Diabetes mellitus and other non-communicable chronic diseases (e.g., cancers, ischemic heart disease, stroke, COPD and asthma) demand an acceptance of change in one's life's prospects and adherence to unceasingly progressive treatment regimens. ${ }^{1}$ Non-communicable chronic diseases were the leading causes of death $(72.3 \%)$ and diabetes mellitus recorded an increase in years of life lost due to premature mortality globally in 2016, when other causes decreased significantly. ${ }^{2}$ The most common type of diabetes mellitus is type 2 diabetes mellitus, accounting for $>90 \%$ of all diabetes cases, and it was the sixth leading cause of disability in $2015 .{ }^{3}$ Diabetes mellitus has long been a global epidemic with about one-third of a billion of the world's population now living with diabetes, ${ }^{4}$ and it is projected to increase to 642 million people by the year $2040 . .^{5}$ By the end of 2015, diabetes mellitus was estimated to have caused 5 million deaths and between USD 673-1,197 billion was spent in annual health care. ${ }^{5}$

People with diabetes mellitus suffer from other chronic diseases as comorbidities or complications such as hypertension, dyslipidemia, cardiovascular diseases (coronary heart disease, cerebrovascular disease and peripheral arterial disease), nephropathy, retinopathy and neuropathy. The complications are a result of suboptimal control of blood glucose, blood pressure and lipids, ${ }^{6,7}$ and negative moods. ${ }^{8-10}$ Type 2 diabetes 
mellitus increases the risk of death from cardiovascular diseases up to four times compared to people who do not have cardiovascular disease. ${ }^{11}$ Early, optimal and appropriate control of these diseases and their risk factors could prevent poor clinical outcomes ${ }^{12-16}$ not only in terms of mortality, but also the morbidity related to these illnesses. ${ }^{17,18}$ It has been shown that well-integrated health systems with improved management of risk factors, advancements in clinical decision-making support, patient education and disease management substantially reduce both mortality and the incidence of cardiovascular outcomes among people with diabetes mellitus compared to the general population. ${ }^{19-22}$

Even when different genetic and environmental factors ${ }^{23}$ are accounted for and the latest advanced and efficacious therapies are used by competent therapists, ${ }^{24-27}$ the outcomes of preventive or curative therapies for diabetes mellitus still depend on the patient's adherence to the prescribed treatments and therapeutic lifestyle recommendations. ${ }^{28-31}$ Notwithstanding the influence that the family, social, economic and political environments have on personal health goals and behaviors; ${ }^{32-35}$ the quality of health systems ${ }^{36,37}$ and physician-patient communication in clinical consultations may also influence health behaviors and affect disease control. ${ }^{38,39}$ Nevertheless, healthseeking behavior and diabetes self-management are very much dependent on the understanding and thinking, feeling and attitudes at a personal level. ${ }^{40-43}$ Patients' contribution to the variance in glycemic control (HbAlc) was found to be as inordinately high as $98 \% .{ }^{44}$ Published data often show that poor adherence to medication, appointments, screening tests, diet, exercise and poor health behaviors were between $30 \%$ and $40 \% .^{29,45}$ Proportion of people with diabetes mellitus who achieved treatment targets for HbAlc $<7.0 \%(<53$ $\mathrm{mmol} / \mathrm{mol}$ ) was at best about $40 \%$, blood pressure $<140 / 90$ $\mathrm{mmHg}$ was $80 \%$ and low-density lipoprotein cholesterol was $60 \% .^{31,46-48}$ The causes for these nonadherent behaviors and persistent suboptimal disease control in people with diabetes mellitus are multiple. ${ }^{49-51}$ Psychological, psychosocial and behavioral interventions aimed at this group of patients in clinical trials have yielded inconsistent effects in clinical outcomes. ${ }^{52}$ This may have been due to differing or insufficient conceptualization of health behavioral theories and models in the interventions. ${ }^{52,53}$ This article attempts to provide a narrative review of psychological approaches and interventions that influence human health behaviors, specifically those that can bring about desirable behavioral adjustment or change in adults with chronic diseases in general and diabetes mellitus in particular. Sustainability of such psychological programs is also briefly discussed.

\section{Materials and methods}

We conducted searches of multiple databases $\left(\mathrm{MEDLINE}^{\circledR}\right.$ via PubMed ${ }^{\circledR}$, Embase $^{\circledR}$, Cochrane Register of Controlled trials, CINAHL [EBSCO], PsycINFO) using terms for emotion, cognition, human/health behavior, psychosocial and psychological aspects in diabetes care in English literatures, including but not limited to MeSH terms for health behaviors, emotional disorders and psychological interventions. Outcomes were not confined to objective disease control. We obtained additional articles from systematic reviews, reference lists of pertinent studies and editorials. We compiled a narrative synthesis of findings, highlighting underlying theories, mechanisms and interactions of the different and essential psychological aspects of people that might explain health behavior in chronic diseases and diabetes mellitus. It is a sequel to our earlier review on the basic aspects of health psychology in effecting behavioral change. ${ }^{53}$ Focus was given to underlying concepts and theories of human health behaviors, and was less on the approaches or delivery methods, and health care systems or policy changes. We provide a brief overview of important considerations to sustain psychological programs and services at health care facilities.

\section{Psychological interventions for behavioral adjustments and self-management}

Underlying psychological mechanisms are determining factors of health behaviors, self-efficacy, successful selfmanagement and quality of life in people with diabetes mellitus. ${ }^{53-66}$ The extent and quality of evidence seemed to vary depending on the type of chronic disease, behavior and outcome targeted, but evidence indicates that theory-driven psychological interventions are likely to result in behavioral change and good outcomes. ${ }^{67,68}$ However, there are inconsistent effects of psychological, psychosocial and behavioral interventions on the clinical outcome parameters such as depressive symptoms, diabetes distress, self-efficacy, selfcare, quality of life and disease control. This might be due to different application and conceptualization of health psychology besides differing approaches in clinical trials. ${ }^{58,59,69-71}$ In the following paragraphs, we assimilate the commonly held concepts, theories ${ }^{53}$ and perspectives of health psychology ${ }^{72}$ in patient-centered empowerment/intervention strategies ${ }^{73,74}$ and put forth a hypothesis that reliable interventions in supporting patient's self-management may have to start from exploring personal value systems (purpose) in life. ${ }^{75,76}$

Earlier reviews ${ }^{77-79}$ and current guidelines ${ }^{80,81}$ have recognized the essential necessity of taking into account a patient's personal and valued goals in order to formulate 
personalized custom-made approaches that promote execution of health-seeking behaviors. Rasmussen et al provided an informative review of the hierarchical goals in affecting action-behavior from the perspective of self-regulation and readjustment of unattainable goal. This is important in the pursue of a valued goal without sacrificing quality of life. ${ }^{82}$ We have begun to see clinical trials evaluating life goals or preferences in people with chronic diseases. ${ }^{83-85}$ Acquiring competency in goal setting and pursuit could potentially enable a person's successful adaptation to life with diabetes and complement health-promoting behaviors that, in turn, lead to enhanced quality of life. ${ }^{86}$ Psychological interventions at the level of the personal value system and life purpose would enhance resilience through improved understanding and health literacy, increasing motivation and ability in using existing social networks around oneself for better illness self-management. ${ }^{87,88}$ Moreover, this type of intervention is consistent with the principle of "to begin with the end in mind", ${ }^{89}$ which will be further expounded below.

\section{Behavioral theories and concepts}

Undisputedly, knowledge and understanding of disease entities are important cognitive processes that can influence health behaviors. Some of the most commonly cited models for health behavior focus on cognitive constructs such as attitudes, beliefs and expectations (related to outcomes, self-belief or what other people might think) and examples of such models include the "Health Belief Model", 90 "Theory of Reasoned Action and Planned Behavior", "P1 "Protection Motivation Theory", "92 "Social Cognitive Theory", ${ }^{3}$ "Self-regulation", ${ }^{44,95}$ "Relapse Prevention Model"96 and others (Table 1). In fact, all these models have cognitive and affective (emotional) components, and most recognize emotions as being the enabler and catalyst of learning in the process that leads to motivation, self-efficacy and behavioral/intentional change. Emotional constructs such as human abilities have been reported to be another important skill that is essential in social functioning, interpersonal relationships and pro-health behaviors. ${ }^{97,98}$ This emotional skill is measured as emotional intelligence improves the life and health of a person through facilitation of accurate reasoning, thought process, self-perception and interpersonal relationships. Some of the important and common concepts of psychological aspects in effecting a behavioral change had been presented in our earlier review. ${ }^{53}$

\section{The psychological framework}

It is clear from the preceding discussion on health behavior theories and models that health behavioral adjustment or change will involve modifications of personal value systems, cognition and emotions. A personal value system consists of valued goals that provide a purpose for living, ${ }^{109}$ which, consciously or unconsciously, are the strength and essence of living; losing these may end up giving up on living and life. When valued goals are congruent with healthful belief systems in terms of knowledge and attitudes toward an illness, these can help to frame or reframe nonthreatening illness perception. ${ }^{110,111}$ Consequently, a new behavior can be formed or an existing behavior can be successfully maintained through proactive coping, physiological adaptation and psychological habituation, leading to resilient health-promoting behaviors that transcend the gene-environmental interdependence throughout the lifespan. ${ }^{112}$

Value systems and the purpose of life have always been related to religious faith or spirituality ${ }^{110}$ and their effects on physical and psychological health are believed to be the result of healthier behaviors as required in the religious teachings, greater social support and having hope that rests on the ultimate or absolute being. ${ }^{113-115}$ Given the underlying importance of value systems and the sense of purpose in life, and the importance of cognition and emotion in human behaviors, the assimilation of these concepts produces a value-based, emotion-focused educational psychological framework in effecting behavioral change (Figure 1). This psychological framework also maps well with the stages of change proposed in the transtheoretical model of health behavior change: ${ }^{116}$ pre-contemplation $\leftrightarrow$ cognition; contemplation and preparation $\leftrightarrow$ emotion/motivation; action $\leftrightarrow$ self-efficacy; maintenance and termination $\leftrightarrow$ resilience/value.

\section{Possible psychological mechanisms of the value-based, emotion-focused education}

The first step in exploring a person's value system is to appeal to the motives for change in regard to a variety of health behaviors. Invariably, it demands a verdict from the person on whether a new or current behavior is either "right" or "wrong", and thus warranting maintenance or change. An awareness of this value system by both the person and the treating physician will provide a clear perspective and direction in clinical consultation, both qualitatively and quantitatively, of what the person needs to know, to change, to do and to maintain. An assessment of a person's pursuit of health as a goal in relation to other goals of life will be helpful in gauging willingness to expend effort toward the same. Considering good health as a prerequisite and foundation to achieve other purposes in life would greatly facilitate learning, health literacy and decision making (cognition), ${ }^{49,117}$ 
Table I Key elements of the common and important health behavior concepts

\begin{tabular}{|c|c|}
\hline $\begin{array}{l}\text { Key developer or } \\
\text { health behavior } \\
\text { concepts }\end{array}$ & Key elements \\
\hline Gonzalez et al ${ }^{99}$ & $\begin{array}{l}\text { Diabetes self-management behaviors may be influenced by three psychosocial domains: } \\
\text { I. Knowledge, beliefs and related cognitive constructs } \\
\text { 2. Emotional distress and well-being } \\
\text { 3. Behavioral skills and coping } \\
\text { Socioeconomic status, cultural beliefs and norms are important context for the above patient-level constructs }\end{array}$ \\
\hline Empowerment ${ }^{100}$ & $\begin{array}{l}\text { Empowerment is seen as a goal and as a means (process, method, approach) that consists of or leads to an increase in the: } \\
\text { I. Control of an individual's (or community's) own health } \\
\text { 2. Ability to control their life } \\
\text { 3. Ability to change the world } \\
\text { Empowerment as a goal requires knowledge, consciousness raising, skills development, self-esteem, self-confidence or self- } \\
\text { efficacy, ability, autonomy and freedom. The idea that empowerment is an approach suggests that the individual or group } \\
\text { should take responsibility themselves for the change process, instead of relying on health care professionals }\end{array}$ \\
\hline Mindfulness ${ }^{101}$ & $\begin{array}{l}\text { Mindfulness involves intentionally bringing one's attention to the internal (such as bodily sensations, thoughts and emotions) } \\
\text { and external (such as sights, smells and sounds) experiences at the present moment with an attitude of nonjudgmental } \\
\text { acceptance (not evaluated as good or bad, true or false, healthy or sick, important or trivial). It aims to detach or decenter } \\
\text { one's thoughts, including statements such as "thoughts are not facts" and "I am not my thoughts." This decentered approach } \\
\text { is also applied to emotions and bodily sensations }\end{array}$ \\
\hline $\begin{array}{l}\text { Self-Determination } \\
\text { Theory (autonomy) } \\
\end{array}$ & $\begin{array}{l}\text { The theory posits that internalization of motivations (or self-regulation) is an active activity and it occurs to satisfy three } \\
\text { innate needs: } \\
\text { I. Autonomy (free will and self-rule) } \\
\text { 2. Competence (self-efficacy) } \\
\text { 3. Relatedness (secure and supportive interpersonal relationships) } \\
\text { Satisfaction of these psychological needs is necessary for successful integration (development), psychological and physical } \\
\text { health and well-being }\end{array}$ \\
\hline $\begin{array}{l}\text { Theory of Planned } \\
\text { Behavior }^{103}\end{array}$ & $\begin{array}{l}\text { The theory of planned behavior is an extension of the theory of reasoned action. It emphasizes cognitive processing of } \\
\text { information and decision making in goal-directed health behaviors. Affect and emotions serve as background factors that } \\
\text { influence intentions and behaviors. Performance of a behavior is a joint function of: } \\
\text { I. Intention to perform a given behavior. Determinants of intentions: } \\
\text { - Attitude toward the behavior } \\
\text { - Subjective norm-perceived social pressure to perform or not to perform the behavior } \\
\text { - Perceived ease or difficulty of performing the behavior - willpower } \\
\text { 2. Salient information or beliefs relevant to the behavior: } \\
\text { - Behavioral beliefs } \\
\text { - Normative beliefs } \\
\text { - Control beliefs }\end{array}$ \\
\hline Moser et al ${ }^{104}$ & $\begin{array}{l}\text { Self-management processes in people with T2DM: } \\
\text { I. Off-course (short term) - in facing with health problems caused by diabetes, becoming aware, reasoning, deciding, acting } \\
\text { and evaluating } \\
\text { 2. Daily activities (long term) - adhering, adapting and acting routinely } \\
\text { 3. Preventive (long term) - experiencing, learning, being cautious and putting into practice } \\
\text { Self-management is deeply embedded in one's unique life situation; it is perceived as an important dimension of personal } \\
\text { autonomy which requires competency. These processes are interwoven, recurring and complex. Support from health care } \\
\text { providers and family caregivers is necessary }\end{array}$ \\
\hline Lorig and Holman ${ }^{41}$ & $\begin{array}{l}\text { Self-management behavior of five core skills: } \\
\text { I. Problem solving } \\
\text { 2. Decision making } \\
\text { 3. Resource utilization } \\
\text { 4. Patient-health care provider partnership } \\
\text { 5. Taking action }\end{array}$ \\
\hline
\end{tabular}


Table I (Continued)

\begin{tabular}{|c|c|}
\hline $\begin{array}{l}\text { Key developer or } \\
\text { health behavior } \\
\text { concept }\end{array}$ & Key elements \\
\hline Corbin and Strauss ${ }^{105}$ & $\begin{array}{l}\text { Self-management framework of three tasks: } \\
\text { I. Medical management - adhering to medication and recommended lifestyle change } \\
\text { 2. Behavioral/role management - changes in social roles or routines as an adaptation to illness } \\
\text { 3. Emotional management }\end{array}$ \\
\hline Social Cognitive & Behavior is determined by expectancies and incentives. Expectancies consist of: \\
\hline $\begin{array}{l}\text { Theory (previously } \\
\text { known as Social }\end{array}$ & $\begin{array}{l}\text { I. Expectancies about environmental cues (beliefs about how events are connected - about what leads to what) } \\
\text { 2. Outcome expectation }\end{array}$ \\
\hline Learning Theory) ${ }^{106}$ & $\begin{array}{l}\text { 3. Efficacy expectation (self-efficacy) } \\
\text { Incentive or reinforcement is defined as the value of a particular object or outcome. Behavior is also regulated by the } \\
\text { (possible) consequences } \\
\text { Cognitive behavioral therapy applies the principles of social cognitive theory in changing human behaviors. Directive } \\
\text { and action-oriented approaches are used to help a person to become aware of own dysfunctional thoughts and actions. } \\
\text { Strategies such as self-monitoring, problem solving, goal setting, contingency management, cognitive restructuring, social } \\
\text { support, stimulus control, stress management and relapse prevention are skills that are taught to the participants }\end{array}$ \\
\hline Health Belief & Health behavior depends on simultaneous occurrence of three factors: \\
\hline Model ${ }^{106,107}$ & $\begin{array}{l}\text { I. Sufficient motivation } \\
\text { 2. Perceived threat } \\
\text { 3. Perceived benefit and perceived barriers in following health recommendation }\end{array}$ \\
\hline $\begin{array}{l}\text { Protection } \\
\text { Motivation Theory } \\
\text { and Self-efficacy }\end{array}$ & $\begin{array}{l}\text { A possible general model of attitude change. The probability of a threat's occurrence (fear appeal) initiates cognitive appraisal } \\
\text { of its severity and believing in possession of an effective coping response (self-efficacy expectancy); both have positive effects } \\
\text { on attitudes and intentions to adopt a recommended preventive health behavior. Four basic components: }\end{array}$ \\
\hline Theory 108 & $\begin{array}{l}\text { I. Outcome expectancy - current behavior } \\
\text { 2. Outcome expectancy - alternative behavior } \\
\text { 3. Self-efficacy (for the alternative behavior) } \\
\text { 4. The relative value of the different sets of outcomes } \\
\text { Two decision-making strategies that people use when confronted with a fear appeal: } \\
\text { I. A precaution strategy (a response is not necessary) } \\
\text { 2. A hyperdefensiveness strategy (the danger cannot be avoided) } \\
\text { A shift to positive emphasis/outcomes was argued to be possible with little modification of the basic components of the } \\
\text { theory }\end{array}$ \\
\hline
\end{tabular}

Abbreviation: T2DM, type 2 diabetes mellitus.

motivation (emotion) and maintenance of healthy lifestyles (self-efficacy), even in the face of life events and challenges (resilience). ${ }^{118}$ Thus, the awareness of a person's values and belief systems with respect to his/her life purpose is important for three specific reasons: 1) to modify perception of the immediate environment; 2) to identify modifiable unhealthy coping styles such as turning to alcohol, increase smoking and so on and 3) to identify the unique internal and external resources available for improving the quality of life and disease control. ${ }^{119}$

This type of psychological intervention may be helpful for people who say "It is not that I don't know what and how to take care of myself but it is just that I don't want to do it" (value problem), compared to people who say "It is not that I don't know what and how to take care of myself but I'm just not able/can't manage to do it" (emotion/motivation problem) or "I don't know what and how to take care of myself" (cognition problem). A mixture of these problems, rather than discrete characterization of values problems, emotion/motivation problems or cognition problems, is believed to be present in most people. Despite this, psychological interventions that address an individual's unique value system separately, besides exploring the possible cause(s) of resistance to pro-health behaviors could help the person to overcome the psychological barriers to healthful behaviors, especially when facing with multiple behavioral choices. This form of intervention is similar to the motivational interviewing as proposed by Hettema et al. ${ }^{120}$ The use of motivational interviewing to induce health-related behavior change is well documented, ${ }^{121,122}$ and has at its basis resolving cognitive dissonance between one's values and one's behaviors, such that this dissonance would provide a motivating force to overcome 


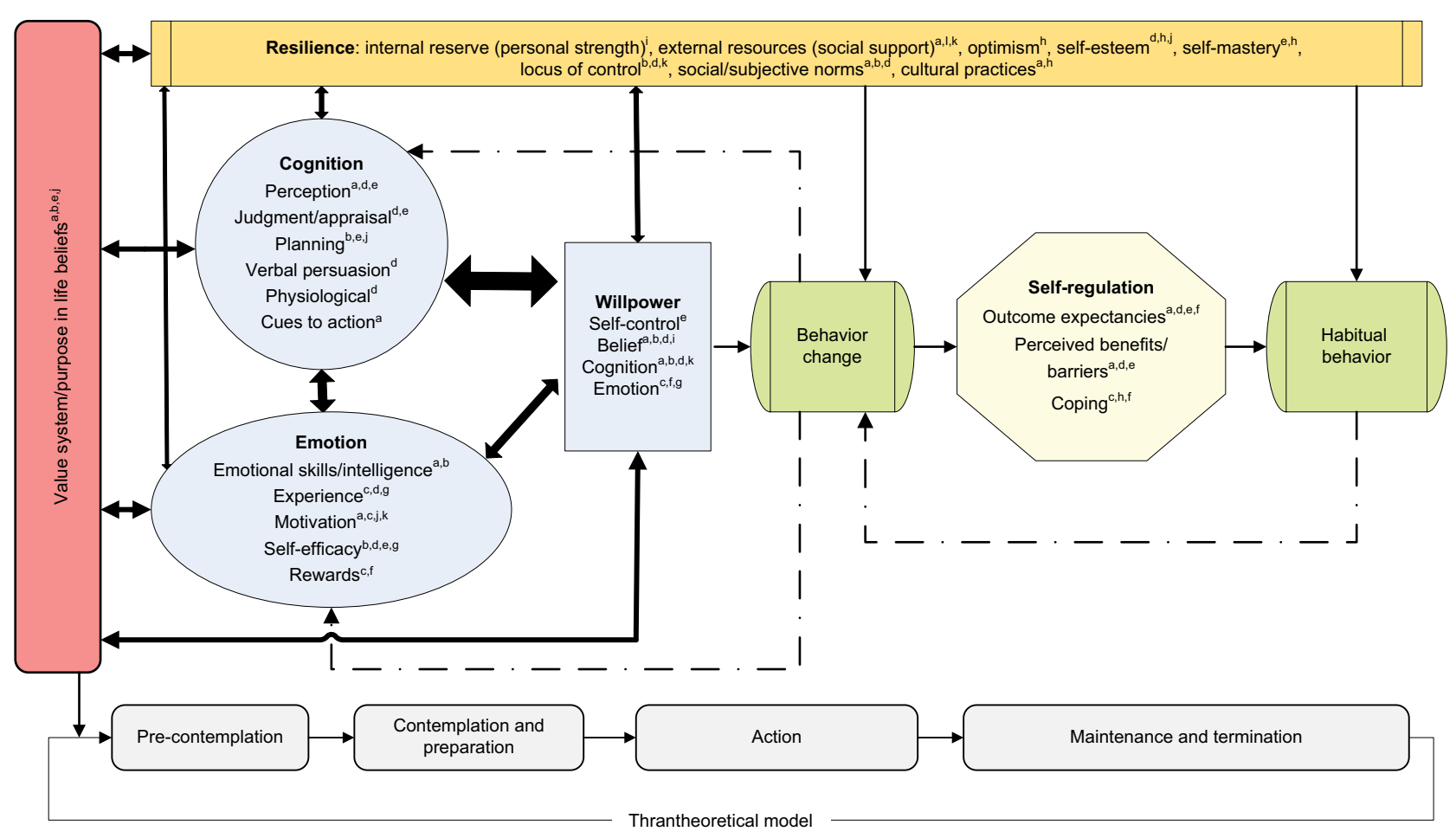

Figure I Value-cognition-emotion psychological framework.

Note: ${ }^{a}$ Health Belief Model; ${ }^{\circ}$ Theory of Reasoned Action and Planned Behavior; 'Protection Motivation Theory; 'Social Cognitive Theory; eSelf-regulation; fRelapse Prevention

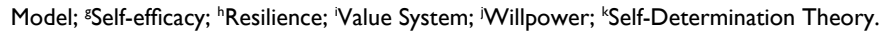

the inertia toward pro-health behaviors. The stronger the awareness of the dissonance, the more likely the person will resolve the dissonance by changing their behaviors to be congruent to their unique values and purpose, or vice versa. This step would help people to come to terms with, and be informed of, their behavioral choices. In some instances, the presence of multiple valued goals in the person may be conflicting to each other such that they compete for limited inner reserves, and this could minimize the motivation toward a certain desired behavior. Thus, alignment, synchronization and/or conglomeration of these personal values are necessary before an effective motivation could be generated. Since a personal value is personal and subjected to the demands of immediate circumstances, it is possible that this personal value system is not a pro-healthy behavior at times ${ }^{50}$ or it may not agree with another person's wants and wishes. However, a personal value that agrees with the universal "good" and "bad" health behaviors prevails and presides in long term.

On the subject of emotions being a driving force to modify behavior, emotional training could provide the necessary emotional skills for people to recognize the emotional information in daily events, and thus gaining insights and energy to effectively managing emotions in themselves and in others toward facilitating productive relationships with self and others, and leading to healthful behaviors. Technical knowledge and skills would then be more effectively learned, retained and applied in the form of new behaviors. The preceding discussion suggests why interventions that work at the cognitive level alone (e.g., educational in nature) were often inadequate for truly forming or altering a behavior, and lesser so in maintaining the required behavior. ${ }^{123}$ Even an intervention at both cognitive and emotional levels may initiate a change in behavior, albeit transiently. Based on the review of human health behavioral theories and concepts, we believe that people who have come to terms with their own values/life purpose would have a more profound understanding about themselves, a meaningful feeling about life and a stronger intention to realize their valued goals in life. This could potentially lead to a greater insight into one's value system, a realignment of cognition, emotion and a new behavior consistent with the realized value system. From another perspective, equipped with sufficient motivation (emotional intelligence) and appropriate knowledge about what and how to behave, an adjustment or a change would lead to a new behavior. This is believed to be a real and meaningful change in a person as compared to the psychological interventions of health-related nudges ${ }^{124}$ and behavioral economics ${ }^{125,126}$ that modify the environmental cues and financial incentives 
to exert or induce a behavioral change, respectively. Regular reinforcement of the upheld values, emotional skills and knowledge is, however, necessary for continuity of the desired behaviors. From a social support perspective, involving the person's spouse or significant others increases the effectiveness of an intervention by serving as an informed companion to support and remind the person. ${ }^{127}$ Thus, initiating a lasting behavior (resilience and self-efficacy) ${ }^{53}$ is more effective when its foundational elements, namely, the personal value system/purpose in life $^{53}$ is assessed and addressed, surpassing the effects of the personal past achievement in social and occupational domains. ${ }^{118}$

\section{Service and program sustainability}

Having psychological and behavioral change services for people with chronic diseases such as diabetes mellitus requires efforts to sustain the services. The sheer burden of diabetes mellitus and its related comorbidities and complications, disease chronicity and treatment complexity demand a sustained support for people with diabetes mellitus. Moreover, a person with diabetes mellitus visits their primary care provider on average four times per year, with an average consultation taking about 20 minutes. ${ }^{128}$ This equates to people with diabetes mellitus spending $<1 \%$ of their lifetime with their doctors and the health care team. However, the successful implementation of such a service requires cooperation on the part of participants to attend the scheduled sessions. ${ }^{129}$ To help in this aspect, the program could be individualized and delivered in its separate simpler sufficient parts to certain types of people, depending on their particular needs such as knowledge, emotional skills or goal setting, or learning about providing social supports by the significant others. ${ }^{80}$ This would make the program more accessible and feasible to more people and their significant others. Additionally, ongoing feedback from the participants and input from the community that is served by the clinics would help to make the program more person centered, culturally relevant, with participant-identified needs, as well as supported by the family of the participants and the local community. ${ }^{80}$

At the clinic level, limitations in terms of logistics and human resources may be barriers to the sustainability of such services. Many smaller or resource-constrained health facilities may face challenges to conduct programs due to facility or staff constraints. Institutional change may also be required to have a functional, and even a dedicated unit, such as a Noncommunicable Disease Unit, staffed by at least one diabetes educator/nurse and one doctor. Service sustainability can also be gained from seeking ongoing input from valued staff and health care providers. This may promote quality and mutual understanding, and enhance participants' referral and utilization. Better organizational or administrative arrangements, such as defining and documenting a mission statement and goals on providing effective programs, will assist in the service continued support and update. ${ }^{80}$

Higher-level stakeholders' involvement in ongoing planning processes will also improve sustainability of the service through sharing of ideas, quality improvement, measurable outcomes, achievement and positive feedback from the community ${ }^{80}$ It is equally important that the administration validates the efforts of their staff and acknowledge appropriate recognition of such services. ${ }^{130}$ Consequently, nurses and doctors conducting the program can experience lesser or no clashes with other clinic duties or with other colleagues. To further improve the sustainability of the service at the clinic, a quality coordinator can be designated to ensure implementation of the program and oversee the overall services including evidence-based practice, service design, evaluation and continuous quality improvement. ${ }^{130}$

\section{Conclusion}

Approaching people with chronic diseases such as diabetes mellitus from the vantage point of their personal value systems and emotional skills besides knowledge does not trade off medical professionalism and commitment to health advancement. On the contrary, this approach is in agreement with the principles of evidence-based medicine, where the personal values and preference of patients are recognized in the formulation of their own treatment plan $^{131}$ and the dynamic definition of health ${ }^{132}$ as "the ability to adapt and self-manage in the face of social, physical, and emotional challenges."

It may be evident from this review that habitual healthful behaviors arise from successful self-regulation and resilience. Successful forming of a new behavior depends on a strong willpower that is fueled by adequate cognizance (understanding and reasoning) and emotional intelligence (motivation and self-efficacy). These become effective when the behavior is highly valued and in line with the purpose of life of the person. Interventional programs and services should consider including all the components in the value-cognition-emotion psychological framework, probably in different appropriate proportions, through culturally appropriate manners in different health care settings, and for people at different illness stages and phases of life. Outcomes and targets of psychological interventions should primarily be psychological measurements and health behaviors and secondarily be the biomarkers of disease control as measured by the laboratory. 
Both are important and supportive of the notions of holistic care and biopsychosocial models of medicine.

\section{Acknowledgments}

We acknowledge Prof Dr Guy EHM Rutten and Asst Prof Dr Rimke C Vos for reading and commenting on some parts of the article. We thank Universiti Putra Malaysia and the Ministry of Higher Education Malaysia for sponsoring the PhD study of BHC, which made possible this work.

\section{Author contributions}

$\mathrm{BHC}$ wrote the first draft. All authors contributed toward data analysis, further drafting and revising the paper and agree to be accountable for all aspects of the work.

\section{Disclosure}

The authors report no conflicts of interest in this work.

\section{References}

1. Chan JC, Luk AO. Diabetes: a cinderella subject we can't afford to ignore. PLoS Med. 2016;13(7):e1002068.

2. GBD 2016 Causes of Death Collaborators. Global, regional, and national age-sex specific mortality for 264 causes of death, 1980-2016: a systematic analysis for the Global Burden of Disease Study 2016. Lancet. 2017;390(10100):1151-1210.

3. GBD 2015 Disease and Injury Incidence and Prevalence Collaborators. Global, regional, and national incidence, prevalence, and years lived with disability for 310 diseases and injuries, 1990-2015: a systematic analysis for the Global Burden of Disease Study 2015. Lancet. 2016;388(10053):1545-1602.

4. Whiting DR, Guariguata L, Weil C, Shaw J. IDF diabetes atlas: global estimates of the prevalence of diabetes for 2011 and 2030. Diabetes Res Clin Pract. 2011;94(3):311-321.

5. International Diabetes Federation. IDF Diabetes Atlas. Brussels, Belgium: International Diabetes Federation; 2015.

6. Jermendy G. Vascular memory: can we broaden the concept of the metabolic memory? Cardiovasc Diabetol. 2012;11(1):44.

7. Konig M, Lamos EM, Stein SA, Davis SN. An insight into the recent diabetes trials: what is the best approach to prevent macrovascular and microvascular complications? Curr Diabetes Rev. 2013;9(5):371-381.

8. Kim D, Kubzansky LD, Baccarelli A, et al. Psychological factors and DNA methylation of genes related to immune/inflammatory system markers: the VA Normative Aging Study. BMJOpen. 2016;6(1):e009790.

9. Laake JP, Stahl D, Amiel SA, et al. The association between depressive symptoms and systemic inflammation in people with type 2 diabetes: findings from the South London Diabetes Study. Diabetes Care. 2014;37(8):2186-2192.

10. Dalsgaard EM, Vestergaard M, Skriver MV, et al. Psychological distress, cardiovascular complications and mortality among people with screen-detected type 2 diabetes: follow-up of the ADDITIONDenmark trial. Diabetologia. 2014;57(4):710-717.

11. Stamler J, Vaccaro O, Neaton JD, Wentworth D. Diabetes, other risk factors, and 12-year cardiovascular mortality for men screened in the Multiple Risk Factor Intervention Trial. Diabetes Care. 1993;16(2):434-444.

12. Gaede P, Vedel P, Larsen N, Jensen GV, Parving HH, Pedersen O. Multifactorial intervention and cardiovascular disease in patients with type 2 diabetes. $N$ Engl J Med. 2003;348(5):383-393.
13. Dailey G. Early and intensive therapy for management of hyperglycemia and cardiovascular risk factors in patients with type 2 diabetes. Clin Ther. 2011;33(6):665-678.

14. Goto A, Arah OA, Goto M, Terauchi Y, Noda M. Severe hypoglycaemia and cardiovascular disease: systematic review and meta-analysis with bias analysis. BMJ. 2013;347:f4533.

15. Boussageon R, Bejan-Angoulvant T, Saadatian-Elahi M, et al. Effect of intensive glucose lowering treatment on all cause mortality, cardiovascular death, and microvascular events in type 2 diabetes: meta-analysis of randomised controlled trials. BMJ. 2011;343:d4169.

16. Wu H, Xu MJ, Zou DJ, Han QJ, Hu X. Intensive glycemic control and macrovascular events in type 2 diabetes mellitus: a meta-analysis of randomized controlled trials. Chin Med J (Engl). 2010;123(20):2908-2913.

17. DeJean D, Giacomini M, Vanstone M, Brundisini F. Patient experiences of depression and anxiety with chronic disease: a systematic review and qualitative meta-synthesis. Ont Health Technol Assess Ser. 2013;13(16):1-33.

18. Nicolucci A, Kovacs Burns K, Holt RI, et al; DAWN2 Study Group. Diabetes Attitudes, Wishes and Needs second study (DAWN2): crossnational benchmarking of diabetes-related psychosocial outcomes for people with diabetes. Diabet Med. 2013;30(7):767-777.

19. Rawshani A, Rawshani A, Franzén S, et al. Mortality and cardiovascular disease in type 1 and type 2 diabetes. NEngl J Med. 2017;376(15): $1407-1418$.

20. Herman WH, Ye W, Griffin SJ, et al. Early detection and treatment of type 2 diabetes reduce cardiovascular morbidity and mortality: a simulation of the results of the Anglo-Danish-Dutch Study of Intensive Treatment in People With Screen-Detected Diabetes in Primary Care (ADDITION-Europe). Diabetes Care. 2015;38(8):1449-1455.

21. Gregg EW, Li Y, Wang J, et al. Changes in diabetes-related complications in the United States, 1990-2010. N Engl J Med. 2014;370(16): 1514-1523.

22. Booth GL, Kapral MK, Fung K, Tu JV. Recent trends in cardiovascular complications among men and women with and without diabetes. Diabetes Care. 2006;29(1):32-37.

23. Chatterjee S, Khunti K, Davies MJ. Type 2 diabetes. Lancet. 2017;389(10085):2239-2251.

24. Naranjo D, Tanenbaum ML, Iturralde E, Hood KK. Diabetes technology: uptake, outcomes, barriers, and the intersection with distress. J Diabetes Sci Technol. 2016;10(4):852-858.

25. Hadjiconstantinou M, Byrne J, Bodicoat DH, et al. Do web-based interventions improve well-being in type 2 diabetes? A systematic review and meta-analysis. $J$ Med Internet Res. 2016;18(10):e270.

26. Pal K, Eastwood SV, Michie S, et al. Computer-based diabetes selfmanagement interventions for adults with type 2 diabetes mellitus. Cochrane Database Syst Rev. 2013;3:Cd008776.

27. Lutfey KE, Wishner WJ. Beyond "compliance" is "adherence". Improving the prospect of diabetes care. Diabetes Care. 1999;22(4):635-639.

28. Messina J, Campbell S, Morris R, Eyles E, Sanders C. A narrative systematic review of factors affecting diabetes prevention in primary care settings. PLoS One. 2017;12(5):e0177699.

29. Cramer JA, Benedict A, Muszbek N, Keskinaslan A, Khan ZM. The significance of compliance and persistence in the treatment of diabetes, hypertension and dyslipidaemia: a review. Int J Clin Pract. 2008;62(1):76-87.

30. Aghili R, Polonsky WH, Valojerdi AE, et al. Type 2 diabetes: model of factors associated with glycemic control. Can J Diabetes. 2016;40(5): 424-430.

31. Edelman SV, Polonsky WH. Type 2 diabetes in the real world: the elusive nature of glycemic control. Diabetes Care. 2017;40(11):1425-1432.

32. Carlin A, Perchoux C, Puggina A, et al. A life course examination of the physical environmental determinants of physical activity behaviour: a "Determinants of Diet and Physical Activity" (DEDIPAC) umbrella systematic literature review. PLoS One. 2017;12(8):e0182083.

33. Coleman MT, Pasternak RH. Effective strategies for behavior change. Prim Care. 2012;39(2):281-305. 
34. Hu FB. Globalization of diabetes: the role of diet, lifestyle, and genes. Diabetes Care. 2011;34(6):1249-1257.

35. Jacob S, Serrano-Gil M. Engaging and empowering patients to manage their type 2 diabetes, Part II: initiatives for success. Adv Ther. 2010;27(10):665-680.

36. Dwamena F, Holmes-Rovner M, Gaulden CM, et al. Interventions for providers to promote a patient-centred approach in clinical consultations. Cochrane Database Syst Rev. 2012;12:CD003267.

37. Renders CM, Valk GD, Griffin S, Wagner EH, Eijk JT, Assendelft WJ. Interventions to improve the management of diabetes mellitus in primary care, outpatient and community settings. Cochrane Database Syst Rev. 2000;(4):CD001481.

38. Alden DL, Friend J, Lee PY, et al. Who decides: me or we? Family involvement in medical decision making in Eastern and Western Countries. Med Decis Making. 2018;38(1):14-25.

39. Low LL, Tong SF, Low WY. Selection of treatment strategies among patients with type 2 diabetes mellitus in Malaysia: a grounded theory approach. PLoS One. 2016;11(1):e0147127.

40. Schulman-Green D, Jaser S, Martin F, et al. Processes of self-management in chronic illness. J Nurs Scholarsh. 2012;44(2):136-144.

41. Lorig KR, Holman H. Self-management education: history, definition, outcomes, and mechanisms. Ann Behav Med. 2003;26(1):1-7.

42. Cortis C, Puggina A, Pesce C, et al. Psychological determinants of physical activity across the life course: a "DEterminants of DIet and Physical Activity" (DEDIPAC) umbrella systematic literature review. PLoS One. 2017;12(8):e182709.

43. Broadbent E, Wilkes C, Koschwanez H, Weinman J, Norton S, Petrie KJ. A systematic review and meta-analysis of the brief illness perception questionnaire. Psychol Health. 2015;30(11):1361-1385.

44. Tuerk PW, Mueller M, Egede LE. Estimating physician effects on glycemic control in the treatment of diabetes: methods, effects sizes, and implications for treatment policy. Diabetes Care. 2008;31(5):869-873.

45. DiMatteo MR. Variations in patients' adherence to medical recommendations: a quantitative review of 50 years of research. Med Care. 2004;42(3):200-209.

46. Feisul MI, Azmi SE, editors. National Diabetes Registry Report, 2009-2012. Volume 1. Kuala Lumpur: Non-Communicable Disease Section, Disease Control Division, Department of Public Health; 2013.

47. Guðbjörnsdóttir S, Eliasson B, Cederholm J, Zethelius B, Ann-Marie S, Samuelsson P. Swedish National Diabetes Register Annual Report 2013. Gothenburg, Sweden: Centre of Registers, Region Västra Götaland; 2014.

48. National Diabetes Audit. National Diabetes Audit - 2015-2016: Report 1, Care Processes and Treatment Targets. England and Wales: Healthcare Quality Improvement Partnership, National Diabetes Audit; 2017.

49. Nam S, Chesla C, Stotts NA, Kroon L, Janson SL. Barriers to diabetes management: patient and provider factors. Diabetes Res Clin Pract. 2011;93(1):1-9.

50. Kodolitsch YV, Bernhardt AM, Kölbel T, Detter C, Reichenspurner H, Debus ES. Maximizing therapeutic success: the key concepts of individualized medical strategy (IMS). Cogent Med. 2015;2:1109742.

51. Luo X, Liu T, Yuan X, et al. Factors influencing self-management in Chinese adults with type 2 diabetes: a systematic review and metaanalysis. Int J Environ Res Public Health. 2015;12(9):11304-11327.

52. Patnode CD, Evans CV, Senger CA, Redmond N, Lin JS. US. Preventive Services Task Force Evidence Syntheses, formerly Systematic Evidence Reviews. In: Behavioral Counseling to Promote a Healthful Diet and Physical Activity for Cardiovascular Disease Prevention in Adults Without Known Cardiovascular Disease Risk Factors: Updated Systematic Review for the US Preventive Services Task Force. Rockville, MD, USA: Agency for Healthcare Research and Quality; 2017.

53. Chew BH, Shariff-Ghazali S, Fernandez A. Psychological aspects of diabetes care: effecting behavioral change in patients. World $J$ Diabetes. 2014;5(6):796-808.
54. Powers MA, Bardsley J, Cypress M, et al. Diabetes self-management education and support in type 2 diabetes: a joint position statement of the American Diabetes Association, the American Association of Diabetes Educators, and the Academy of Nutrition and Dietetics. Diabetes Care. 2015;38(7):1372-1382.

55. Sturt J, Taylor H, Docherty A, Dale J, Louise T. A psychological approach to providing self-management education for people with type 2 diabetes: the diabetes manual. BMC Fam Pract. 2006;7(1):70.

56. Robertson SM, Stanley MA, Cully JA, Naik AD. Positive emotional health and diabetes care: concepts, measurement, and clinical implications. Psychosomatics. 2012;53(1):1-12.

57. Robertson SM, Amspoker AB, Cully JA, Ross EL, Naik AD. Affective symptoms and change in diabetes self-efficacy and glycaemic control. Diabet Med. 2013;30(5):e189-e196.

58. Harkness E, Macdonald W, Valderas J, Coventry P, Gask L, Bower P. Identifying psychosocial interventions that improve both physical and mental health in patients with diabetes: a systematic review and meta-analysis. Diabetes Care. 2010;33(4):926-930.

59. Baumeister H, Hutter N, Bengel J. Psychological and pharmacological interventions for depression in patients with diabetes mellitus and depression. Cochrane Database Syst Rev. 2012;12:CD008381.

60. Brierley S, Eiser C, Johnson B, Young V, Heller S. Psychological interventions for young people with type 1 diabetes: a metaanalysis. Diabet Med. 2013;30:177-178.

61. Deakin T, McShane CE, Cade JE, Williams RD. Group based training for self-management strategies in people with type 2 diabetes mellitus. Cochrane Database Syst Rev. 2005;(2):CD003417.

62. Duke SA, Colagiuri S, Colagiuri R. Individual patient education for people with type 2 diabetes mellitus. Cochrane Database Syst Rev. 2009;(1):CD005268.

63. Franek J. Self-management support interventions for persons with chronic disease: an evidence-based analysis. Ont Health Technol Assess Ser. 2013;13(9):1-60.

64. Pal K, Eastwood SV, Michie S, et al. Computer-based interventions to improve self-management in adults with type 2 diabetes: a systematic review and meta-analysis. Diabetes Care. 2014;37(6):1759-1766.

65. van Dam HA, van der Horst FG, Knoops L, Ryckman RM, Crebolder HF, van den Borne BH. Social support in diabetes: a systematic review of controlled intervention studies. Patient Educ Couns. 2005;59(1):1-12.

66. Winkley K, Ismail K, Landau S, Eisler I. Psychological interventions to improve glycaemic control in patients with type 1 diabetes: systematic review and meta-analysis of randomised controlled trials. BMJ. 2006;333(7558):65.

67. Zhao FF, Suhonen R, Koskinen S, Leino-Kilpi H. Theory-based selfmanagement educational interventions on patients with type 2 diabetes: a systematic review and meta-analysis of randomized controlled trials. J Adv Nurs. 2017;73(4):812-833.

68. Barley E, Lawson V. Using health psychology to help patients: theories of behaviour change. Br J Nurs. 2016;25(16):924-927.

69. Ismail K, Winkley K, Rabe-Hesketh S. Systematic review and metaanalysis of randomised controlled trials of psychological interventions to improve glycaemic control in patients with type 2 diabetes. Lancet. 2004;363(9421):1589-1597.

70. Sturt J, Dennick K, Hessler D, Hunter BM, Oliver J, Fisher L. Effective interventions for reducing diabetes distress: systematic review and meta-analysis. Int Diab Nurs. 2015;12(2):40-55.

71. Chew BH, Vos RC, Metzendorf MI, Scholten RJ, Rutten GE. Psychological interventions for diabetes-related distress in adults with type 2 diabetes mellitus. Cochrane Database Syst Rev. 2017;9: CD011469.

72. Riekert KA, Ockene JK, Pbert L, editors. The Handbook of Health Behavior Change, 4th ed. New York: Springer Publishing Company; 2013.

73. Serrano-Gil M, Jacob S. Engaging and empowering patients to manage their type 2 diabetes, part I: a knowledge, attitude, and practice gap? Adv Ther. 2010;27(6):321-333. 
74. Funnell MM, Tang TS, Anderson RM. From DSME to DSMS: developing empowerment-based diabetes self-management support. Diab Spectr. 2007;20(4):221-226.

75. Lynch CP, Hernandez-Tejada MA, Strom JL, Egede LE. Association between spirituality and depression in adults with type 2 diabetes. Diabetes Educ. 2012;38(3):427-435.

76. Rasmussen NH, Smith SA, Maxson JA, et al. Association of HbA1c with emotion regulation, intolerance of uncertainty, and purpose in life in type 2 diabetes mellitus. Prim Care Diabetes. 2013;7(3):213-221.

77. Grimaldi A. How to help the patient motivate himself? Diabetes Metab. 2012;38 (Suppl 3):S59-S64.

78. Ahola AJ, Groop PH. Barriers to self-management of diabetes. Diabet Med. 2013;30(4):413-420.

79. Rothman AJ. Initiatives to motivate change: a review of theory and practice and their implications for older adults. In: Carstensen LL, Hartel CR, editors. When I'm 64. Washington, DC, USA: National Academies Press; 2006.

80. Beck J, Greenwood DA, Blanton L, et al. 2017 National standards for diabetes self-management education and support. Diabetes Care. 2017;40(10):1409-1419.

81. Scottish Intercollegiate Guidelines Network. Management of Diabetes: A National Clinical Guideline. Guideline No 116. Edinburgh: Healthcare Improvement Scotland; 2010.

82. Rasmussen HN, Wrosch C, Scheier MF, Carver CS. Self-regulation processes and health: the importance of optimism and goal adjustment. J Pers. 2006;74(6):1721-1747.

83. Arends RY, Bode C, Taal E, Van de Laar MA. The role of goal management for successful adaptation to arthritis. Patient Educ Couns. 2013;93(1):130-138.

84. Zhang Y, Tikkinen KA, Agoritsas T, et al. Patients' values and preferences of the expected efficacy of hip arthroscopy for osteoarthritis: a protocol for a multinational structured interview-based study combined with a randomised survey on the optimal amount of information to elicit preferences. BMJ Open. 2014;4(10):e005536.

85. Chew BH, Vos RC, Shariff Ghazali S, et al. The effectiveness of a value-based EMOtion-cognition-focused educational programme to reduce diabetes-related distress in Malay adults with type 2 diabetes (VEMOFIT): study protocol for a cluster randomised controlled trial. BMC Endocr Disord. 2017;17(1):22.

86. Stuifbergen AK, Morris M, Jung JH, Pierini D, Morgan S. Benefits of wellness interventions for persons with chronic and disabling conditions: a review of the evidence. Disabil Health J. 2010;3(3):133-145.

87. Bailey SC, Brega AG, Crutchfield TM, et al. Update on health literacy and diabetes. Diabetes Educ. 2014;40(5):581-604.

88. Cavanaugh K, Wallston KA, Gebretsadik T, et al. Addressing literacy and numeracy to improve diabetes care: two randomized controlled trials. Diabetes Care. 2009;32(12):2149-2155.

89. Covey SR. The 7 Habits of Highly Effective People. New York: Simon \& Schuster: 2013.

90. Rosenstock IM. Why people use health services. Milbank Mem Fund Q. 1966;44(3):Suppl:94-127.

91. Ajzen I. The theory of planned behaviour: reactions and reflections. Psychol Health. 2011;26(9):1113-1127.

92. Rogers RW. A protection motivation theory of fear appeals and attitude change1. J Psychol. 1975;91(1):93-114.

93. Bandura A. Social cognitive theory: an agentic perspective. Annu Rev Psychol. 2001;52(1):1-26.

94. Clark NM, Gong M, Kaciroti N. A model of self-regulation for control of chronic disease. Health Educ Behav. 2001;28(6):769-782.

95. Denise de Ridder, John de Wit, editors. Self-Regulation in Health Behavior. West Sussex, England: John Wiley \& Sons; 2006.

96. Hendershot CS, Witkiewitz K, George WH, Marlatt GA. Relapse prevention for addictive behaviors. Subst Abuse Treat Prev Policy. 2011;6:17.

97. Mayer JD, Roberts RD, Barsade SG. Human abilities: emotional intelligence. Annu Rev Psychol. 2007;59(1):507-536.
98. Abraham R. Emotional competence as antecedent to performance: a contingency framework. Genet Soc Gen Psychol Monogr. 2004;130(2):117-143.

99. Gonzalez JS, Tanenbaum ML, Commissariat PV. Psychosocial factors in medication adherence and diabetes self-management: implications for research and practice. Am Psychol. 2016;71(7):539-551.

100. Tengland PA. Empowerment: a conceptual discussion. Health Care Anal. 2008;16(2):77-96.

101. Baer RA. Mindfulness training as a clinical intervention: a conceptual and empirical review. Clin Psychol Science Pract. 2003;10(2):125-143.

102. Ryan RM, Deci EL. Self-determination theory and the facilitation of intrinsic motivation, social development, and well-being. Am Psychol. 2000;55(1):68-78.

103. Ajzen I. The theory of planned behavior. Theories Cogn Self Regul. 1991;50(2):179-211.

104. Moser A, van der Bruggen H, Widdershoven G, Spreeuwenberg C. Self-management of type 2 diabetes mellitus: a qualitative investigation from the perspective of participants in a nurse-led, shared-care programme in the Netherlands. BMC Public Health. 2008;8:91.

105. Corbin JM, Strauss A. Unending Work and Care: Managing Chronic Illness at Home (Jossey Bass Social and Behavioral Science Series). San Francisco, CA: Jossey-Bass; 1988.

106. Rosenstock IM, Strecher VJ, Becker MH. Social learning theory and the health belief model. Health Educ Q. 1988;15(2):175-183.

107. Janz NK, Becker MH. The health belief model: a decade later. Health Educ Q. 1984;11(1):1-47.

108. Maddux JE, Rogers RW. Protection motivation and self-efficacy: a revised theory of fear appeals and attitude change. J Exp Soc Psychol. 1983;19(5):469-479.

109. Scheier MF, Wrosch C, Baum A, et al. The life engagement test: assessing purpose in life. J Behav Med. 2006;29(3):291-298.

110. Myers DG. The funds, friends, and faith of happy people. Am Psychol. 2000;55(1):56-67.

111. Petrie KJ, Jago LA, Devcich DA. The role of illness perceptions in patients with medical conditions. Curr Opin Psychiatry. 2007;20(2): $163-167$.

112. Aspinwall LG. The psychology of future-oriented thinking: from achievement to proactive coping, adaptation, and aging. Motiv Emotion. 2005;29(4):203-235.

113. McCullough ME, Willoughby BL. Religion, self-regulation, and selfcontrol: associations, explanations, and implications. Psychol Bull. 2009;135(1):69-93.

114. Newlin K, Melkus GD, Tappen R, Chyun D, Koenig HG. Relationships of religion and spirituality to glycemic control in Black women with type 2 diabetes. Nurs Res. 2008;57(5):331-339.

115. Okun MA, Stock WA. Correlates and components of subjective wellbeing among the elderly. J Appl Gerontol. 1987;6(1):95-112.

116. Prochaska JO, DiClemente CC. Self change processes, self efficacy and decisional balance across five stages of smoking cessation. Prog Clin Biol Res. 1984;156:131-140.

117. Lee YK, Low WY, Ng CJ. Exploring patient values in medical decision making: a qualitative study. PLoS One. 2013;8(11):e80051.

118. Mertens VC, Bosma H, Groffen DA, van Eijk JT. Good friends, high income or resilience? What matters most for elderly patients? Eur $J$ Public Health. 2012;22(5):666-671.

119. Rose M, Fliege H, Hildebrandt M, Schirop T, Klapp BF. The network of psychological variables in patients with diabetes and their importance for quality of life and metabolic control. Diabetes Care. 2002;25(1):35-42.

120. Hettema J, Steele J, Miller WR. Motivational interviewing. Annu Rev Clin Psychol. 2005;1:91-111.

121. Rubak S, Sandbæk A, Lauritzen T, Christensen B. Motivational interviewing: a systematic review and meta-analysis. Br J Gen Pract. 2005;55(513):305-312.

122. Treasure J. Motivational interviewing. Adv Psychiatr Treat. 2004;10(5): $331-337$. 
123. Sperl-Hillen J, Beaton S, Fernandes O, et al. Are benefits from diabetes self-management education sustained? Am J Manag Care. 2013;19(2):104-112.

124. Marteau TM. Changing minds about changing behaviour. Lancet. 2018;391(10116):116-117.

125. Volpp KG, Pauly MV, Loewenstein G, Bangsberg D. P4P4P: an agenda for research on pay-for-performance for patients. Health Aff (Millwood). 2009;28(1):206-214.

126. Reed DD, Niileksela CR, Kaplan BA. Behavioral economics: a tutorial for behavior analysts in practice. Behav Anal Pract. 2013;6(1):34-54.

127. Rintala TM, Jaatinen P, Paavilainen E, Astedt-Kurki P. Interrelation between adult persons with diabetes and their family: a systematic review of the literature. J Fam Nurs. 2013;19(1):3-28.
128. Ahmad BA, Khairatul K, Farnaza A. An assessment of patient waiting and consultation time in a primary healthcare clinic. Malays Fam Physician. 2017;12(1):14-21.

129. Swerissen H, Crisp BR. The sustainability of health promotion interventions for different levels of social organization. Health Promot Int. 2004;19(1):123-130.

130. Gruen RL, Elliott JH, Nolan ML, et al. Sustainability science: an integrated approach for health-programme planning. Lancet. 2008;372(9649): 1579-1589.

131. Sackett DL, Rosenberg WM, Gray JA, Haynes RB, Richardson WS. Evidence based medicine: what it is and what it isn't. BMJ. 1996;312(7023):71-72.

132. Huber M, Knottnerus JA, Green L, et al. How should we define health? BMJ. 2011;343:d4163.
Psychology Research and Behavior Management

\section{Publish your work in this journal}

Psychology Research and Behavior Management is an international, peerreviewed, open access journal focusing on the science of psychology and its application in behavior management to develop improved outcomes in the clinical, educational, sports and business arenas. Specific topics covered in the journal include: Neuroscience, memory and decision making; Behavior
Submit your manuscript here: https://www.dovepress.com/psychology-research-and-behavior-management-journal

\section{Dovepress}

modification and management; Clinical applications; Business and sports performance management; Social and developmental studies; Animal studies. The manuscript management system is completely online and includes a very quick and fair peer-review system, which is all easy to use. Visit http://www. dovepress.com/testimonials.php to read real quotes from published authors. 